\title{
GATING System DeSign AND OPTIMIZATION IN SAND Mold Casting of CAST Irons
}

\author{
Erbul, A.; VAnl, A. S.; AKdogan, A. \& Durakbasa, N.
}

Abstract: Casting process parameters should be adjusted as optimum to meet customer requirements. Computer aided simulation is a unique way to determine optimum process parameters and to predict possible risks and casting defects. Since there are several defect types, estimation of process risks and taking precautions quickly and precisely before the production with the help of computer simulation is a must for casting processes. In this study, unpressurized gating system design for ductile iron casting is investigated. Choke area which effects molten metal velocity and pouring time directly is calculated. The sprue and gates are designed according to the calculations. Satisfactory results were achieved when the casting part specifications and simulation outputs were compared.

Key words: Sand casting, gating system design, simulation, optimization, cast iron.
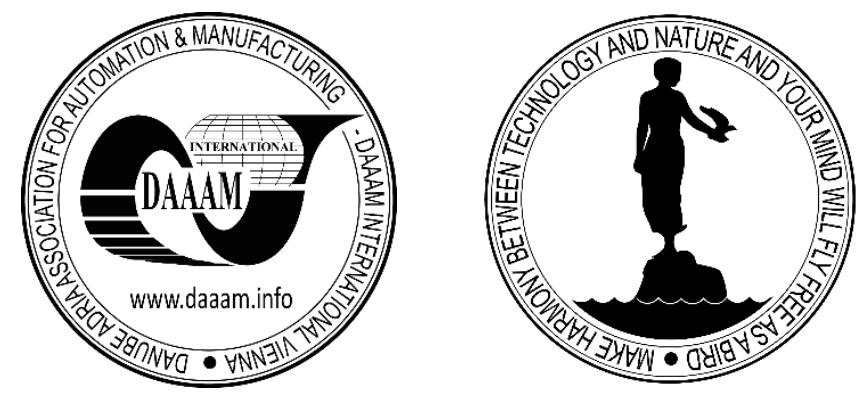

Authors' data: MSc. Erbul, A[tahan $]^{*}$, Dr. Vanli, A[li] S[erdar]*, Assoc. Prof. Dr. Akdogan, A[nil]*, Prof. Dr. Durakbasa, N[uman]**, *Yildiz Technical University, Mechanical Engineering Department, Istanbul, Turkey, **Vienna University of Technology, Department for Interchangeable Manufacturing and Industrial Metrology, Institute of Production Engineering and Laser Technology, Vienna, Austria, atahan.erbul@hotmail.com,_svanli@yildiz.edu.tr,_nomak@yildiz.edu.tr, durakbasa@tuwien.ac.at

This Publication has to be referred as: Erbul, A[tahan]; Vanli, A[li] S[erdar]; Akdogan, A[nil] \& Durakbasa, N[uman] (2017). Gating System Design and Optımization in Sand Mold Casting of Cast Irons, Chapter 14 in DAAAM International Scientific Book 2017, pp.173-190, B. Katalinic (Ed.), Published by DAAAM International, ISBN 978-3-902734-12-9, ISSN 1726-9687, Vienna, Austria

DOI:10.2507/daaam.scibook.2017.14 
Erbul, A.; Vanli, A. S.; Akdogan, A. \& Durakbasa, N.: Gating System Design and ...

\section{Introduction}

Casting is the manufacturing technique that has many process parameters. Because of that, meeting the customer requirements is very difficult. In order to reach the desirable quality in casting, well designed gating system is the first step. Dimensions of the gating system's members need to be calculated according to product geometry since each part has different shape and an incorrect design is the root cause of the defects which can be detected on the surfaces or within the parts, mostly. There is a wide variety of casting defects. Shrinkage porosity, gas porosity, sand defects, slag defects, short run and cold shut are the common ones. High molten metal velocity, long pouring time, low permeability, poor feeding system and filtration or incorrect vent placement can cause these kinds of defects (AFS, 1947), (TUDOKSAD, 1999). Therefore, all process should be investigated in detail.

Today, there is a fierce competition between the companies for gaining a place in the market. Therefore, the companies should serve the best at the cheapest cost. Predicting the possible risks before the casting is important to avoid the defects and decrease the scrap rate. Simulation is helpful way for obtaining that. Basically, a simulation program creates a virtual reality and provides an opportunity to observe the processes before production. It makes the risks detectable and under favour of that, the precautions can be taken, earlier. It reflects on the scrap rate and production cost, positively (Erbul, 2017). Additionally, in all areas of the manufacturing, the produced parts have quite complex shapes. It is necessary to shorten time when new products are started to be produced. It is suitable to use modern simulation software. This kind of software programs are able to show weak points of process and it is possible to optimize it virtually without stopping production line (Raz et all., 2016).

In this study, a gating system is calculated for a cast iron project part and simulations for molten metal velocity, porosity, temperature are run and simulation outputs are evaluated. The tooling which is designed according to data is manufactured and then the production is realized. Visual and x-ray inspections are done and one part is sectioned. Results are compared with the simulation outputs.

\section{Gating System}

Gating system is composed of various parts. Those are pouring basin, sprue and sprue well, runner and gates (Fig. 1). Pouring basin is the first location where the molten metal flows in the mold cavity. Molten metal reaches the sprue after passing through pouring basin. Sprue conveys it to the sprue well. Sprue well is the place where the flow direction is changed to horizontal from vertical. Besides, it provides a laminar flow to molten metal to avoid sand erosion and air entrapment. Liquid metal flows in runner and then reaches the gates. Since sand erosion that can be occurred during the molten metal flowing in the runner and gates can affect the part quality directly, the liquid metal velocity should be kept under control in those areas (Erbul \& Vanli, 2017). Desired characteristics of an ideal gating system can be seen in Table 1. Gating system serves different purposes and the most important one is conveying the molten metal into the mold cavity. Choke area is the tightest area of the system and it controls the 
filling time and liquid metal velocity. There are two types of gating systems according to choke area location. If it is located at the sprue, then this system is called unpressurized gating system. If the choke location is at the gate, it is called pressurized gating system (Fig. 2). Comparison of unpressurized and pressurized gating systems characteristics can be seen in Table 2 .

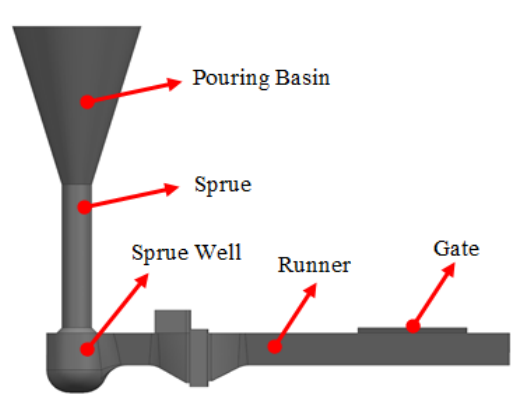

Fig. 1. Schematic drawing of a gating system in sand mold casting.

\begin{tabular}{|l|l|}
\hline Requirements & Example \\
\hline $\begin{array}{l}\text { Molten metal velocity should be kept } \\
\text { between critical limits (max. \& min.) } \\
\text { by gating system. }\end{array}$ & $\begin{array}{l}\text { If the velocity is high, it can cause sand } \\
\text { erosion and gas entrapment or if the } \\
\text { velocity is slow, solidification can start } \\
\text { before the cavity is fully filled. }\end{array}$ \\
\hline $\begin{array}{l}\text { Gating system should be designed } \\
\text { optimal in the point of flow rate. }\end{array}$ & $\begin{array}{l}\text { If the system design is not optimal, waste } \\
\text { of metal increases and the fettling } \\
\text { operations gets harder. }\end{array}$ \\
\hline $\begin{array}{l}\text { Gating system should provide a } \\
\text { laminar flow and minimize } \\
\text { turbulence. }\end{array}$ & $\begin{array}{l}\text { If the flow is turbulent, it can cause gas } \\
\text { entrapment and sand erosion. }\end{array}$ \\
\hline $\begin{array}{l}\text { The gating system should convey the } \\
\text { molten metal to mold cavity and } \\
\text { solidify after the part. }\end{array}$ & $\begin{array}{l}\text { If the gating system can't convey the } \\
\text { molten metal to mold cavity or it solidifies } \\
\text { before the part, metal flow be precluded } \\
\text { and the mold cavity does not fill. }\end{array}$ \\
\hline $\begin{array}{l}\text { Gating system should prevent entry of } \\
\text { slag, dross, inclusions to mold cavity. }\end{array}$ & $\begin{array}{l}\text { Slag, dross and inclusions scrap the } \\
\text { casting parts. }\end{array}$ \\
\hline
\end{tabular}

Tab. 1. The tasks of ideal gating system (ASM, 1998).

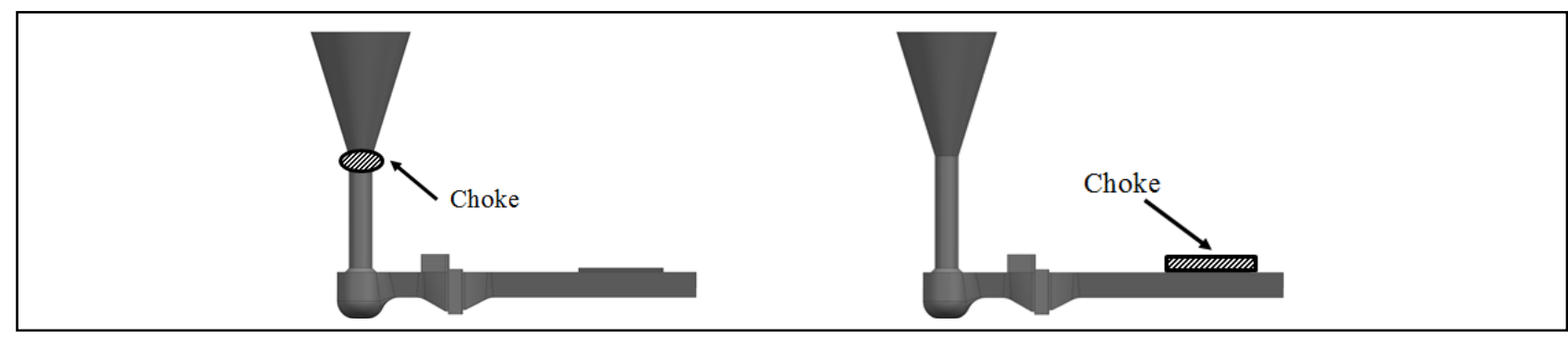

Fig. 2. Unpressurized (left) and pressurized (right) gating systems. 
Erbul, A.; Vanli, A. S.; Akdogan, A. \& Durakbasa, N.: Gating System Design and ...

\begin{tabular}{|l|l|}
\hline Unpressurized Gating System & Pressurized Gating System \\
\hline Choke is located at sprue & Choke is located at gate(s) \\
\hline $\begin{array}{l}\text { Molten metal velocity decreases from } \\
\text { sprue to gate(s) }\end{array}$ & $\begin{array}{l}\text { Molten metal velocity increases from } \\
\text { sprue to gate(s) }\end{array}$ \\
\hline Turbulence possibility is minimized & Turbulence risk is high \\
\hline $\begin{array}{l}\text { Correct design is needed to keep full the } \\
\text { system. }\end{array}$ & $\begin{array}{l}\text { Gating system is kept full due to } \\
\text { geometry. }\end{array}$ \\
\hline $\begin{array}{l}\text { Provide an equal flow is more difficult at } \\
\text { gates. }\end{array}$ & Liquid velocity is almost same at gates. \\
\hline $\begin{array}{l}\text { Since gate sections are enlarged, fettling } \\
\text { operations are tough. }\end{array}$ & $\begin{array}{l}\text { Fettling operations are easier due to } \\
\text { gate geometry. }\end{array}$ \\
\hline
\end{tabular}

Tab. 2. Comparison of unpressurized and pressurized gating systems (Demircioglu, 2013).

\section{Gating System Design}

Gating system should provide a laminar flow for molten metal from the ladle to the mold cavity and also avoid the entry of inclusions to the mold cavities. Design of gating system starts with calculation of the choke area.

$\mathrm{C}_{\mathrm{A}}=\frac{22,6 \times \mathrm{W}}{\rho x \xi \times \mathrm{t} x \sqrt{\mathrm{H}}}$

$\mathrm{C}_{\mathrm{A}}$ : Choke area $\left(\mathrm{cm}^{2}\right)$

$\mathrm{W}$ : Total metal weight $(\mathrm{kg})$

$\rho$ : Density of liquid metal $\left(\mathrm{g} / \mathrm{cm}^{3}\right)$

$\xi$ : Friction factor (dimensionless)

t: Pouring time (s)

$\mathrm{H}$ : Effective pouring height $(\mathrm{cm})$

The tables and formulas help to determine the parameters which are needed for calculation the choke area. There are three types of effective pouring height calculation. It depends on part layout in the mold.

The entire part can be in drag (Fig. 3.). The ' $\mathrm{H}$ ' is calculated by the equation which is stated below, in this case.

$\mathrm{H}=\mathrm{h}$ 


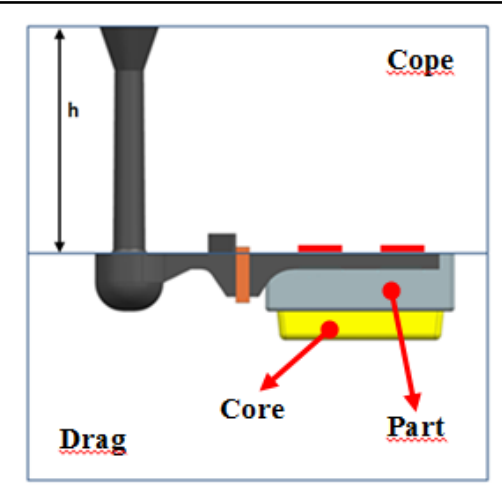

Fig. 3. The part is in drag completely.

The entire part can be in cope (Fig. 4). The ' $\mathrm{H}$ ' is calculated by the equation which is indicated below, then.

$$
\mathrm{H}=\mathrm{h}-\frac{\mathrm{c}}{2}
$$

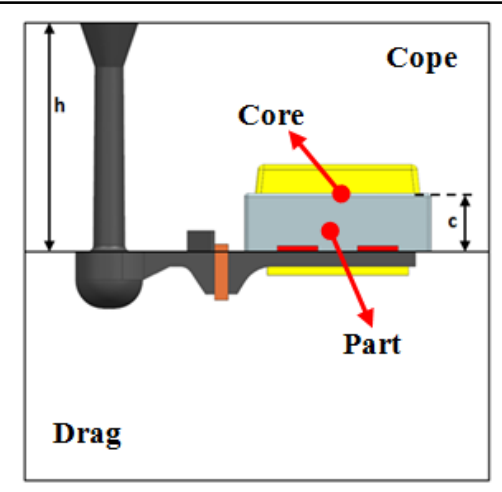

Fig. 4. The part is in cope completely.

The part can be in cope and drag (Fig. 5). To calculate the ' $\mathrm{H}$ ', the following equation can be used, in the present case.

$\mathrm{H}=\mathrm{h}-\frac{\mathrm{a}^{2}}{2 \mathrm{c}}$

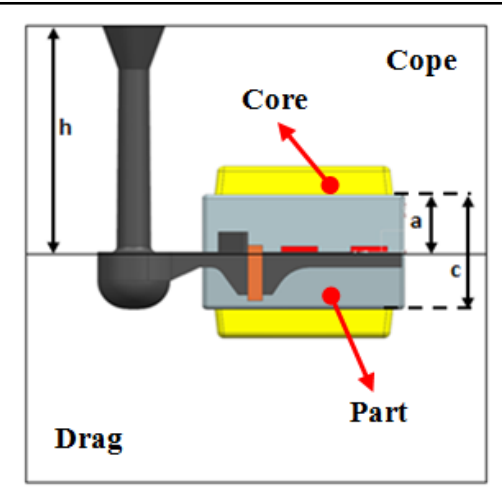

Fig. 5. The part is in cope and drag. 
Erbul, A.; Vanli, A. S.; Akdogan, A. \& Durakbasa, N.: Gating System Design and ...

Another parameter is pouring time. In order to determine it approximately, the diagram which is shown in (Fig. 6) can be used.

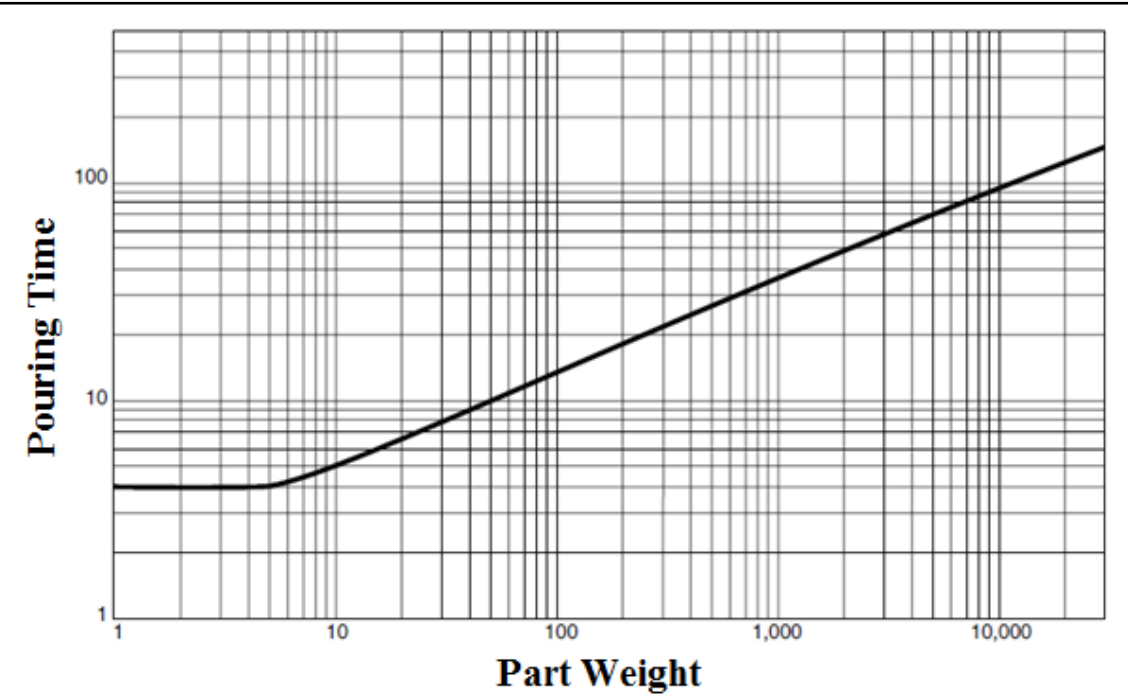

Fig. 6. Part weight-Pouring time diagram (Rio-Tinto Iron and Titanium Inc., 2000).

Friction factor is between $0,2-0,6$ in generally. It depends on mold geometry and metal type (Brown, 2000). 0,4 is an acceptable assumption. Ductile cast iron is the metal type of this project which is the member of the ferrous alloys. It is one of the most preferred material in casting since its good mechanical properties and low production cost. There are different grades of cast iron and the density parameter depends on material type as known (Cavusoglu, 1981), (Odabasi, 2004), (Davis, 1996), (Bodsworth, 2001).

Total metal weight, in another saying gross weight, is connected with the part geometry, gating system design and feeders. After determining the all values, $\mathrm{C}_{\mathrm{A}}$ can be calculated by the equation 1 . Cross section dimensions of runner and gates should be calculated after finding $\mathrm{C}_{\mathrm{A}}$. As mentioned before, if system is unpressurized, the sections enlarge from sprue to gates. Unpressurized gating systems can be designed according to recommended rates for choke's, runner's, and gate's section areas as shown in Table 3. If system is pressurized, section areas tighten from sprue to gates and several recommended design rates are shown in Table 4.

\begin{tabular}{|c|c|c|}
\hline Sprue & Runner & Gate \\
\hline 1 & 1,1 & 1,2 \\
\hline 1 & 1,2 & 1,6 \\
\hline 1 & 1,5 & 2,0 \\
\hline
\end{tabular}

Tab. 3. Recommended rates for section areas of unpressurized gating system.

\begin{tabular}{|c|c|c|}
\hline Sprue & Runner & Gate \\
\hline 1,6 & 1,3 & 1 \\
\hline 1,4 & 1,2 & 1 \\
\hline 1,2 & 1,1 & 1 \\
\hline
\end{tabular}

Tab. 4. Recommended rates for section areas of pressurized gating system. 
Filtration is needed for production quality. During pouring, sands, inclusions, slag can enter the mold cavity within liquid metal. The filters are used for avoiding this problem (Fig. 7). As the others, the filter dimensions have to be calculated according to gross weight and material type (Tab. 5). Besides that, filter's pore intensity depends on the material fluidity.

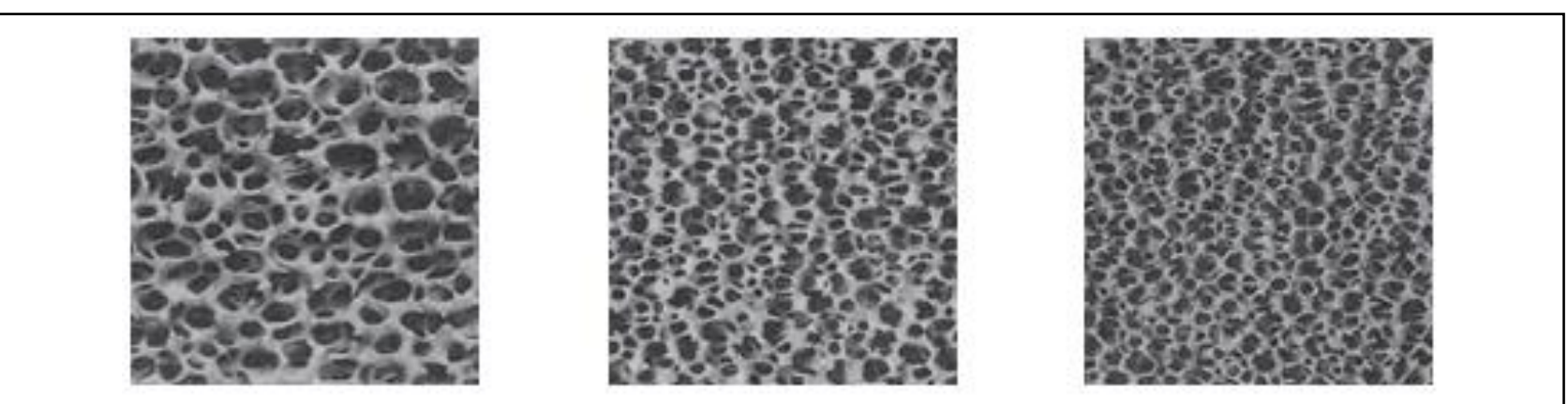

Fig. 7. 10 ppi - 20 ppi - 30 ppi filters' images, respectively (Brown, 2000).

\begin{tabular}{|l|l|l|}
\hline Material & ppi & Filtration Capacity $\mathbf{( k g / \mathbf { c m } ^ { 2 } )}$ \\
\hline Ductile Iron & 10 & 1,5 \\
\hline Grey Iron & 20 & 4 \\
\hline Malleable Cast Iron & 30 & 4 \\
\hline
\end{tabular}

Tab. 5. Filter characteristics according to material type (Brown, 2000).

Filter section area is calculated with the equation which is stated below.

$\mathrm{A}_{\text {filter }}=\frac{\mathrm{W}}{\mathrm{n} \cdot \mathrm{fc}}$

$\mathrm{A}_{\text {filter}}:$ Filter section area $\left(\mathrm{cm}^{2}\right)$

W: Gross weight $(\mathrm{kg})$

$\mathrm{n}$ : Filter quantity (dimensionless)

fc: Filtration capacity $\left(\mathrm{kg} / \mathrm{cm}^{2}\right)$

\section{Gating System Design of the Project Part}

The project part is chosen as differential housing (Fig. 8). The part weight is 23 $\mathrm{kg}$ and its material is EN-GJS-450-10 (EN 1563:2001, 2011). That material is ductile iron grade. The supporter foundry has several production lines and these have different dimensions and pouring basin geometries (Fig. 9). According to the part geometry, the layout is with two cavities as shown in Fig. 10. To determine the gross weight approximately, a rough gating system design is required. It is created by Siemens NX 9 CAD software (Fig. 10). The gross weight can be calculated by CAD software. But the density value has to be inputted to the program, firstly. The part material is ENGJS-450-10 as stated before. Its density value is $7,1 \mathrm{gr} / \mathrm{cm}^{3}$. The gross weight equals to $62,5 \mathrm{~kg}$ according to the result (Fig. 11). 


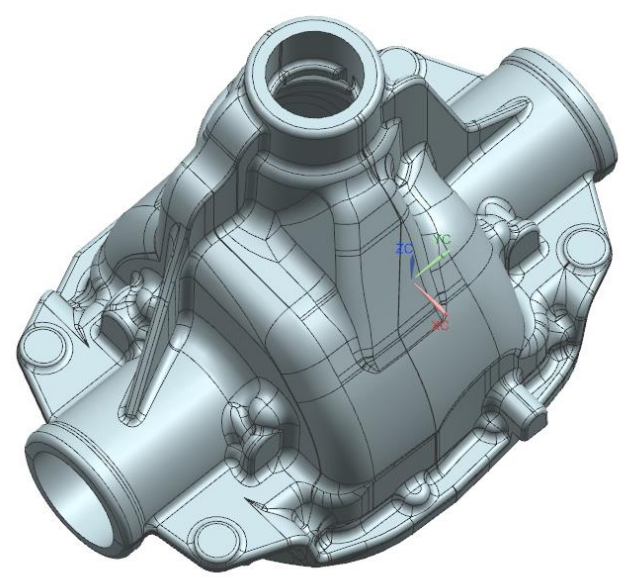

Fig. 8. The project part.

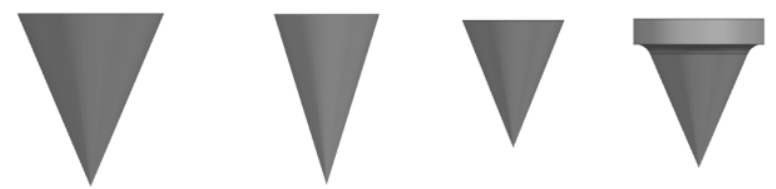

Fig. 9. The pouring basing geometries of the lines.

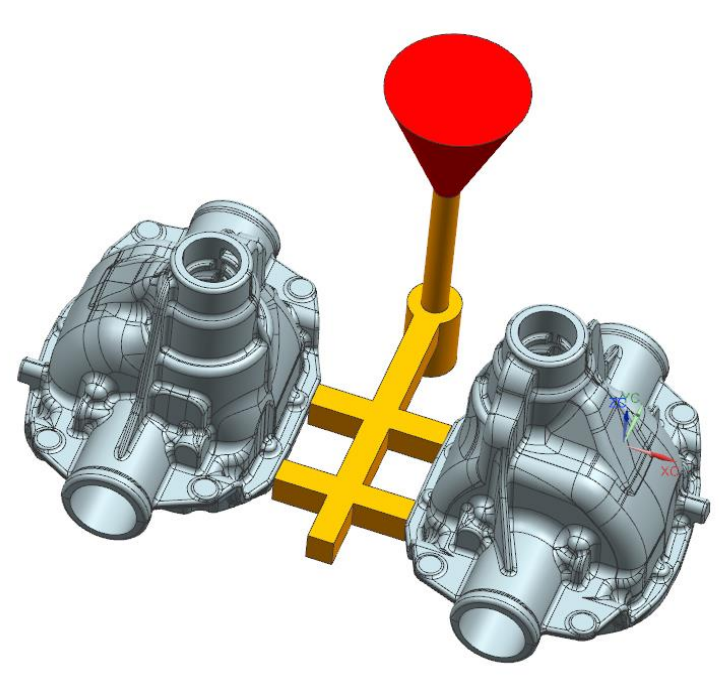

Fig. 10. The rough gating system design.

Determination of the parting line is important for calculation of the effective pouring height. According to the part design (draft angles etc.), the parting line is as shown in Fig. 12. and it seems that the part is in drag and cope.

To calculate the effective pouring height, $h$, a, and $c$ dimensions have to be determined. According to the measurement results from CAD data, ' $c$ ' dimension is measured $279 \mathrm{~mm}$ and ' $\mathrm{a}$ ' dimension is measured $265 \mathrm{~mm}$. The ' $\mathrm{h}$ ' dimension is the cope height. And the cope height is $360 \mathrm{~mm}$ for the production line which is chosen to 
pour the project part. After determining the required dimensions, the ' $\mathrm{H}$ ' can be calculated.

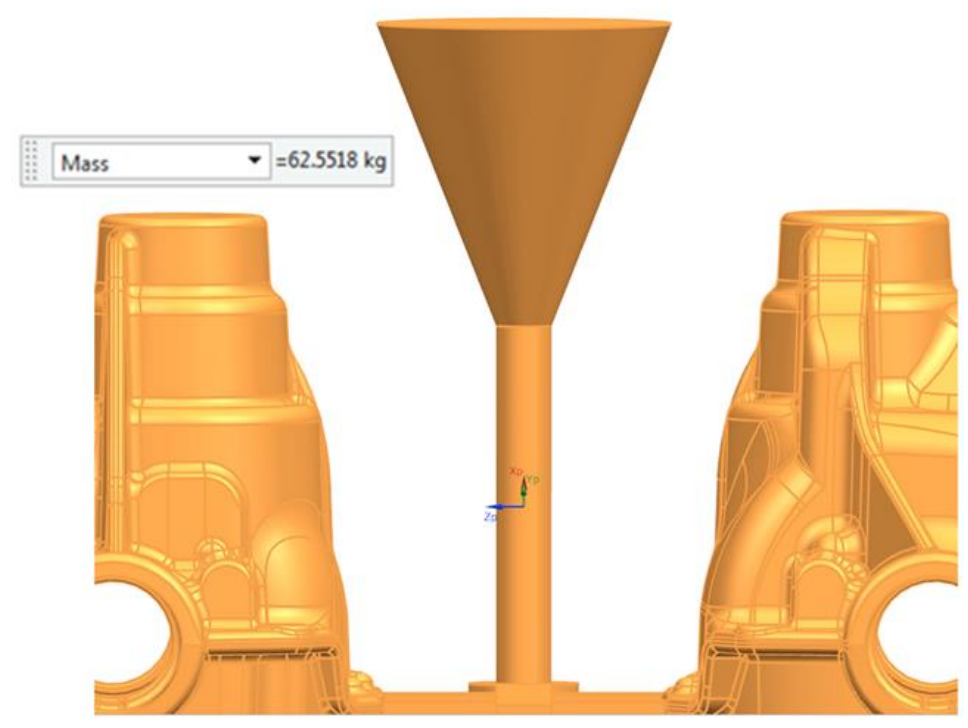

Fig. 11. The gross weight.

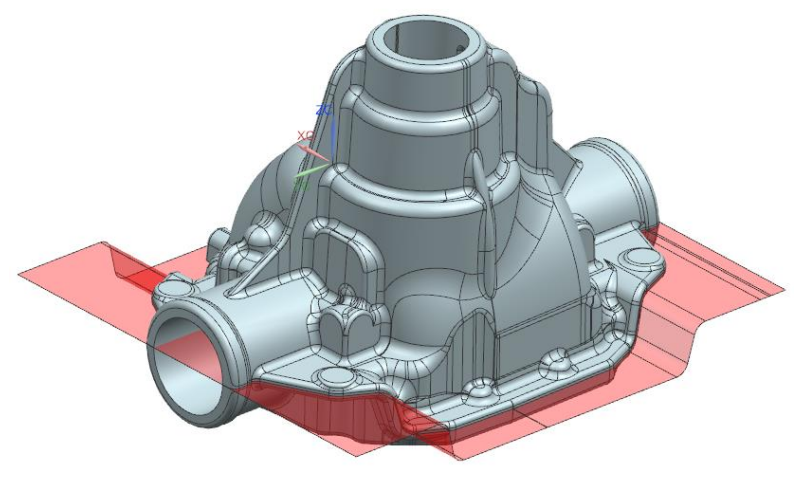

Fig. 12. The parting line of the project part.

$\mathrm{H}=\mathrm{h}-\frac{\mathrm{a}^{2}}{2 \mathrm{c}}=360-\frac{265^{2}}{2 \times 279}=234 \mathrm{~mm}=23,4 \mathrm{~cm}$

$\sqrt{\mathrm{H}}=\sqrt{23,4 \mathrm{~cm}}=4,83 \mathrm{~cm}$

Another parameter pouring time can be determined from the Part weight - Pouring time diagram as shown in Fig. 6 . According to $62,5 \mathrm{~kg}$ gross weight, the pouring time is found about $11 \mathrm{~s}$, if the lines that are plotted from the values are intersected. The friction factor value can be considered as 0,4 . As stated before, this value is acceptable assumption for this project. Density of EN-GSJ-450-10 is $7,1 \mathrm{gr} / \mathrm{cm}^{3}$. Since all the parameters are ready, $\mathrm{C}_{\mathrm{A}}$ (Fig. 13) can be calculated now.

$\mathrm{C}_{\mathrm{A}}=\frac{22,6 \times 62,5}{7,1 \times 0,4 \times 11 \times 4,83}=9,36 \mathrm{~cm}^{2}$ 
Erbul, A.; Vanli, A. S.; Akdogan, A. \& Durakbasa, N.: Gating System Design and ...

$9,36 \mathrm{~cm}^{2}=936 \mathrm{~mm}^{2}$

$936=\mathrm{r}_{\text {sprue }}^{2} x \pi$

$\mathrm{r}_{\text {sprue }}=17,26 \mathrm{~mm} \approx 17 \mathrm{~mm}$

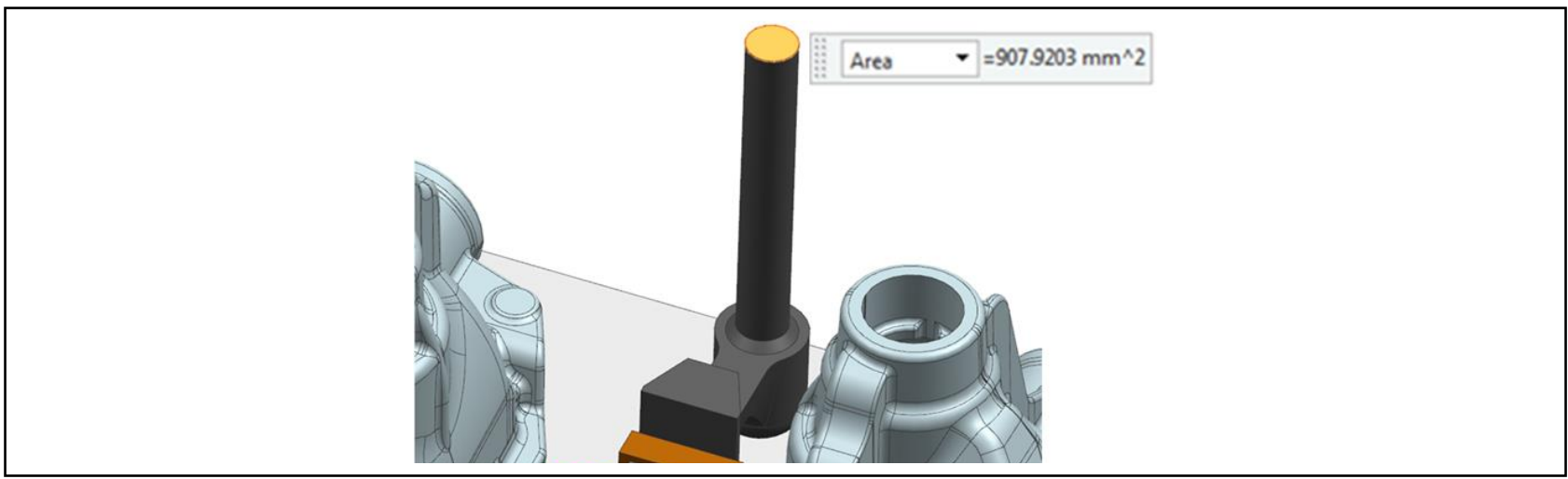

Fig. 13. Measurement of choke area.

$1: 1,2: 1,6$ rate is used to calculate section areas of gating system. This rate depends on the designer. It can be selected different. ' $\mathrm{R}_{\mathrm{A}}$ ' is the section area value of the runner and ' $a_{R}$ ' is the length of short base of trapezoid (Fig. 14).

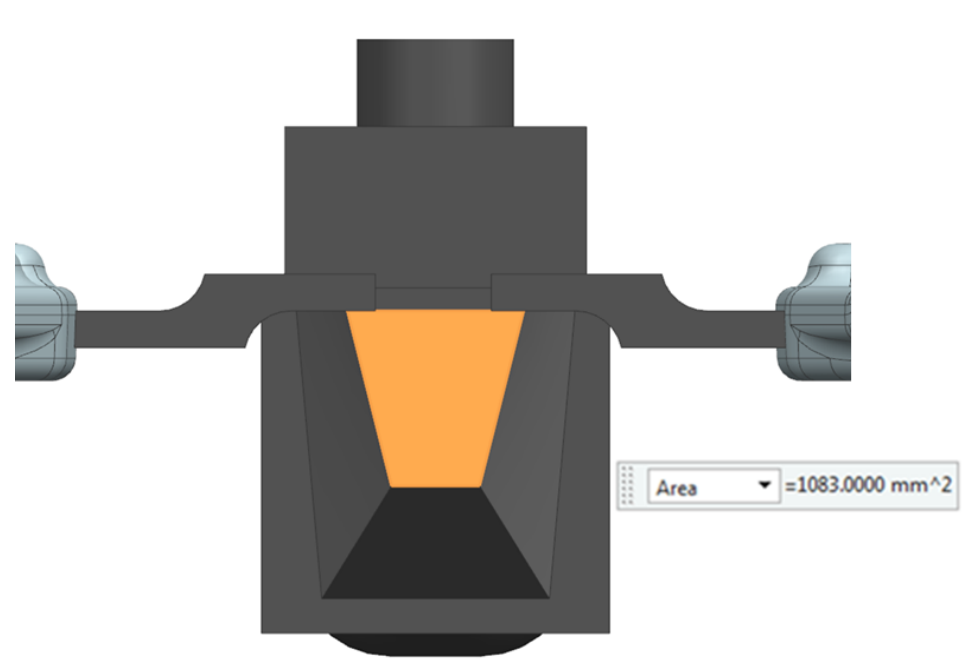

Fig. 14. Measurement of runner section area.

$\mathrm{C}_{\mathrm{A} \text {,pattern }}=\mathrm{r}_{\text {sprue,pattern }}^{2} x \pi$

$\mathrm{C}_{\mathrm{A}, \text { pattern }}=17^{2} \times \pi=907,9 \mathrm{~mm}^{2}$

$\mathrm{R}_{\mathrm{A}}=\mathrm{C}_{\mathrm{A}, \text { pattern }} x 1,2=907,9 \times 1,2 \approx 1089,4 \mathrm{~mm}^{2}$

$1089,4=\frac{(\mathrm{a}+2 \mathrm{a}) \times 2 \mathrm{a}}{2}=3 \mathrm{a}^{2}$ 
$\mathrm{a}_{\mathrm{R}} \approx 19 \mathrm{~mm}$

As defined ' $\mathrm{G}_{\mathrm{A}}$ ' is the total section area value of the gates. The gates' dimensions are considered as same. Therefore, the total area is divided by four to find one of them (Fig. 15).

$$
\begin{aligned}
& \mathrm{G}_{\mathrm{A}}=\mathrm{C}_{\mathrm{A}, \text { pattern }} \times 1,6=907,9 \times 1,6=1452,6 \mathrm{~mm}^{2} \\
& \mathrm{MG}_{\mathrm{A}, 1}=\mathrm{MG}_{\mathrm{A}, 2}=\mathrm{MG}_{\mathrm{A}, 3}=\mathrm{MG}_{\mathrm{A}, 4}
\end{aligned}
$$

$\frac{1452,6}{4}=363,1 \mathrm{~mm}^{2}$

Dimensions of the gate are determined $8 \mathrm{~mm}$ and $45 \mathrm{~mm}$ according to consideration of section area value and optimization of the fettling operations. After the simulations, these dimensions can be optimized if any risks are detected.

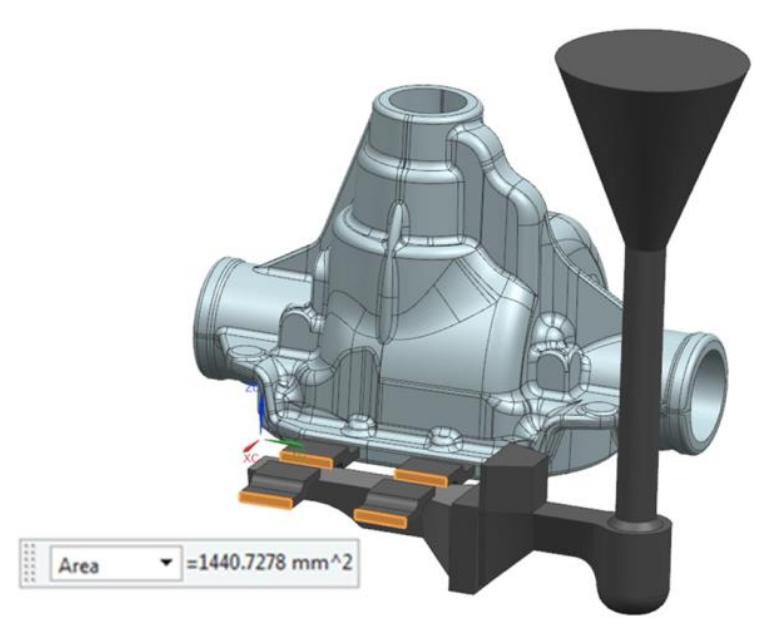

Fig. 15. Measurement of gates section areas.

Another decision that has to be taken is filter type. The filter selection is made according to following equation. A filter value gives an idea about the minimum limit of filter section area that should be. According to result, a proper filter should be chosen from the related catalog. In this project, Foseco Sedex $75 \times 75 \times 22 \mathrm{~mm}$ filter is used. But it can be changed due to tight layout or high slag possibility.

$$
\begin{aligned}
& A_{\text {filter }}=\frac{62,5}{1.1,5} \approx 41,6 \mathrm{~cm}^{2} \\
& A_{\text {filter }}=4160 \mathrm{~cm}^{2}<75 x 75=5625 \mathrm{~mm}^{2}
\end{aligned}
$$


Erbul, A.; Vanli, A. S.; Akdogan, A. \& Durakbasa, N.: Gating System Design and ...

\section{Simulation of the Project Part}

The gating system is created by CAD software according to calculations. The simulation is run with the CAD data. MAGMA 5.2 is used in this project as simulation software. Before running simulations, some basic adjustments have to be made. These basic adjustments are alloy type, process mode, sand type, pouring temperature and material type.

In addition, the program has to be calibrated according to foundry conditions for getting accurate results. By the way, the chemical composition can be adjusted if a specific study is required. In this project, adjustments are as shown below.

- Alloy type: Iron alloys

- Process mode: Sand mold casting

- Sand type: Green sand

- Pouring temperature: $1400{ }^{\circ} \mathrm{C}$

- Material: EN-GJS-450-10

According to Fig. 16, the velocity values are about $1 \mathrm{~m} / \mathrm{s}$ and no risk is detected after filter according to the simulation output as shown in Fig. 17. If erosion risk is detected after filter, design should be reviewed until problem is solved.

According to Fig. 18, cold shut risk is detected because the purple colored areas which stay cold during solidification. Porosity risks are detected for several areas, as shown in Fig.19.

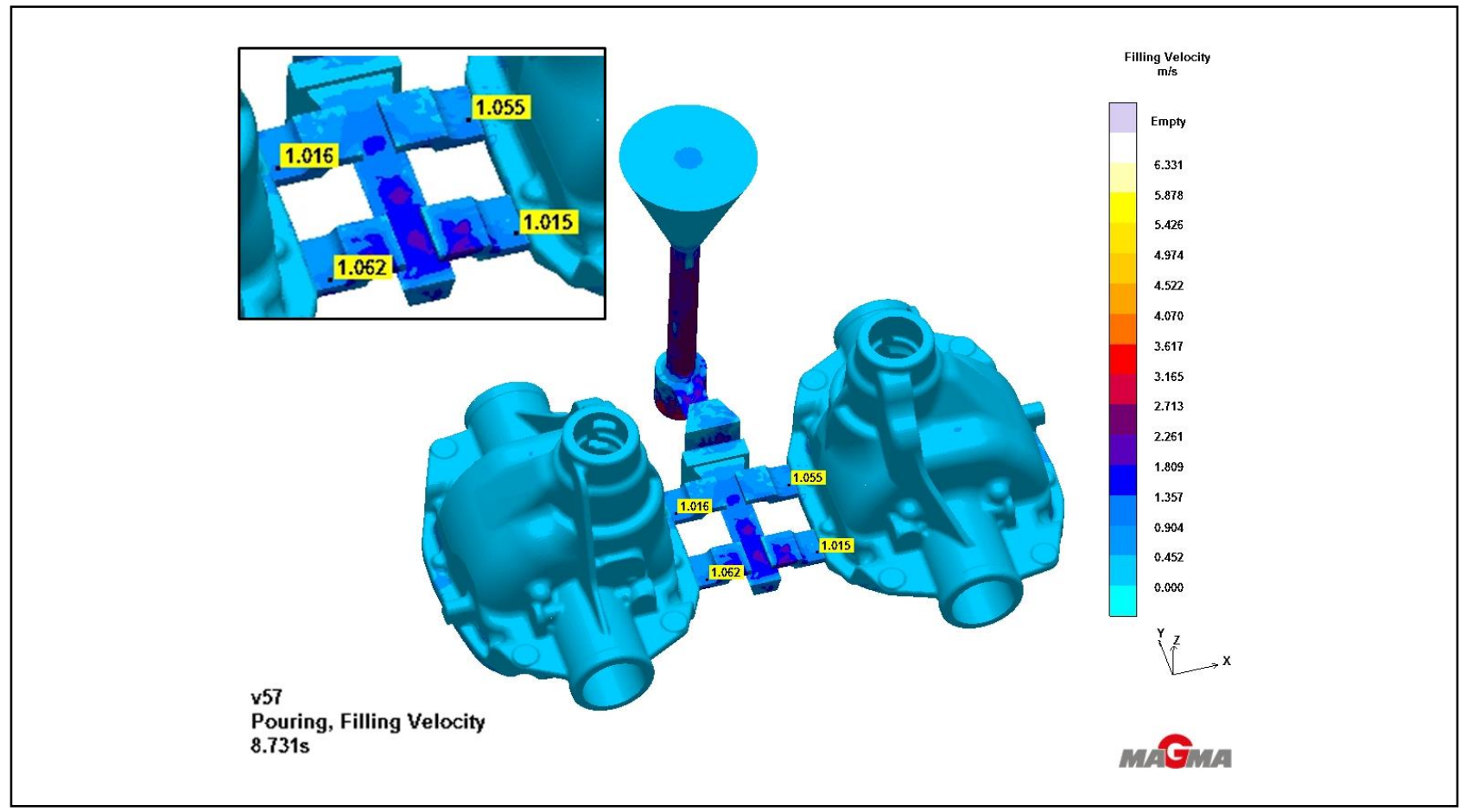

Fig. 16. Molten metal velocity at the gates. 


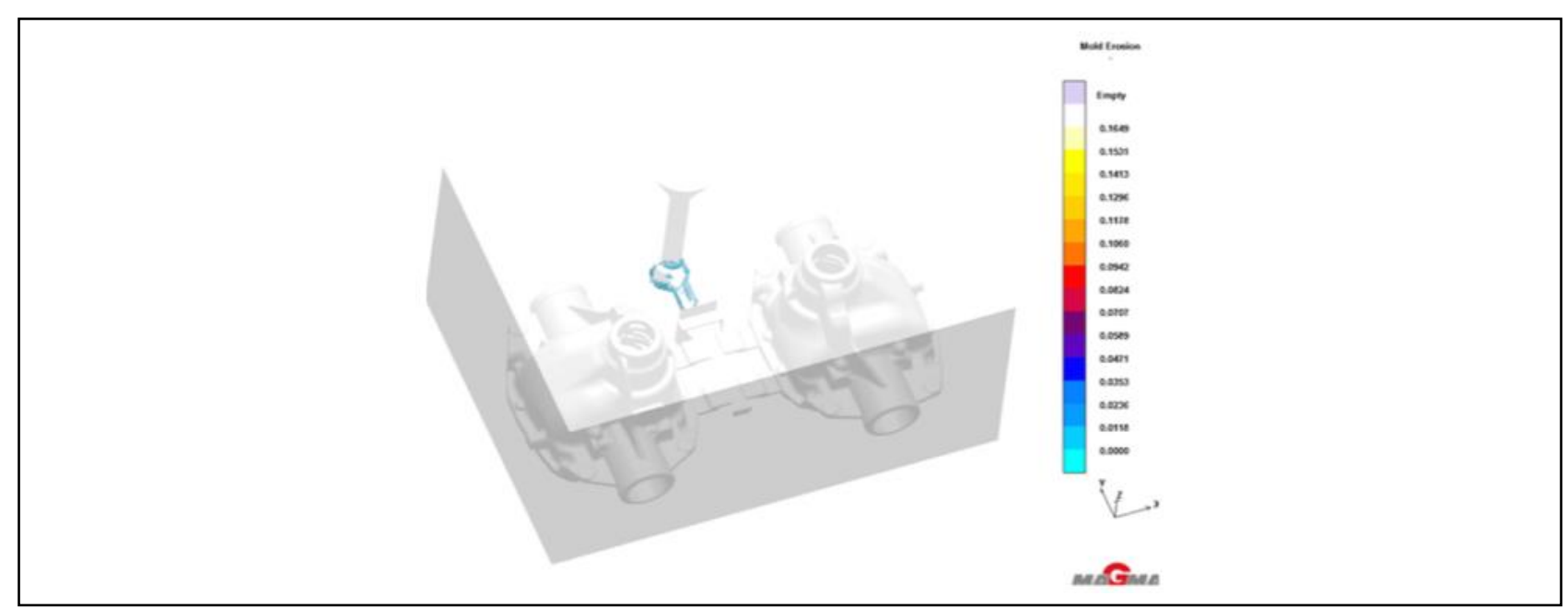

Fig. 17. Mold erosion risk.

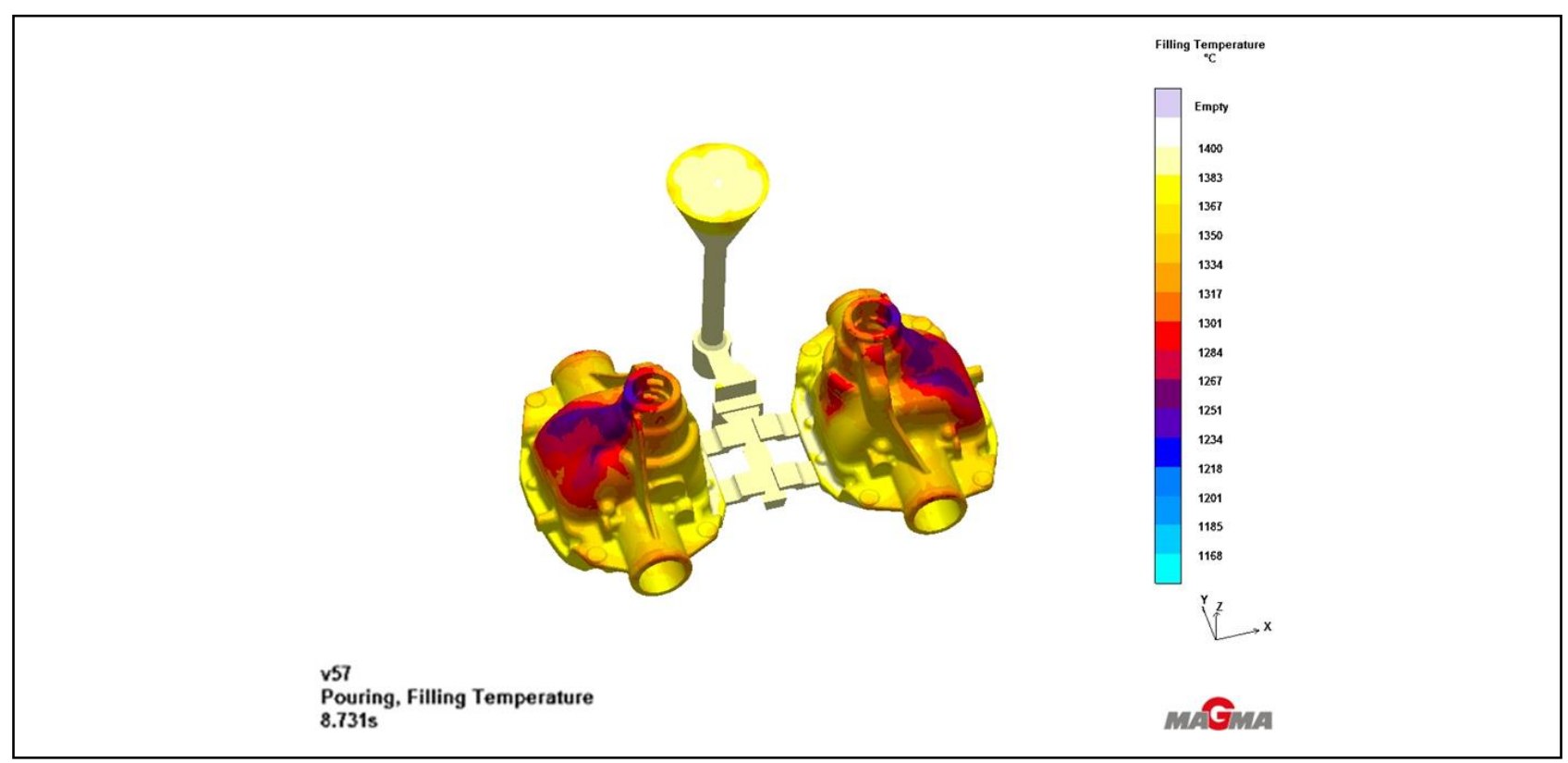

Fig. 18. Temperature distribution.

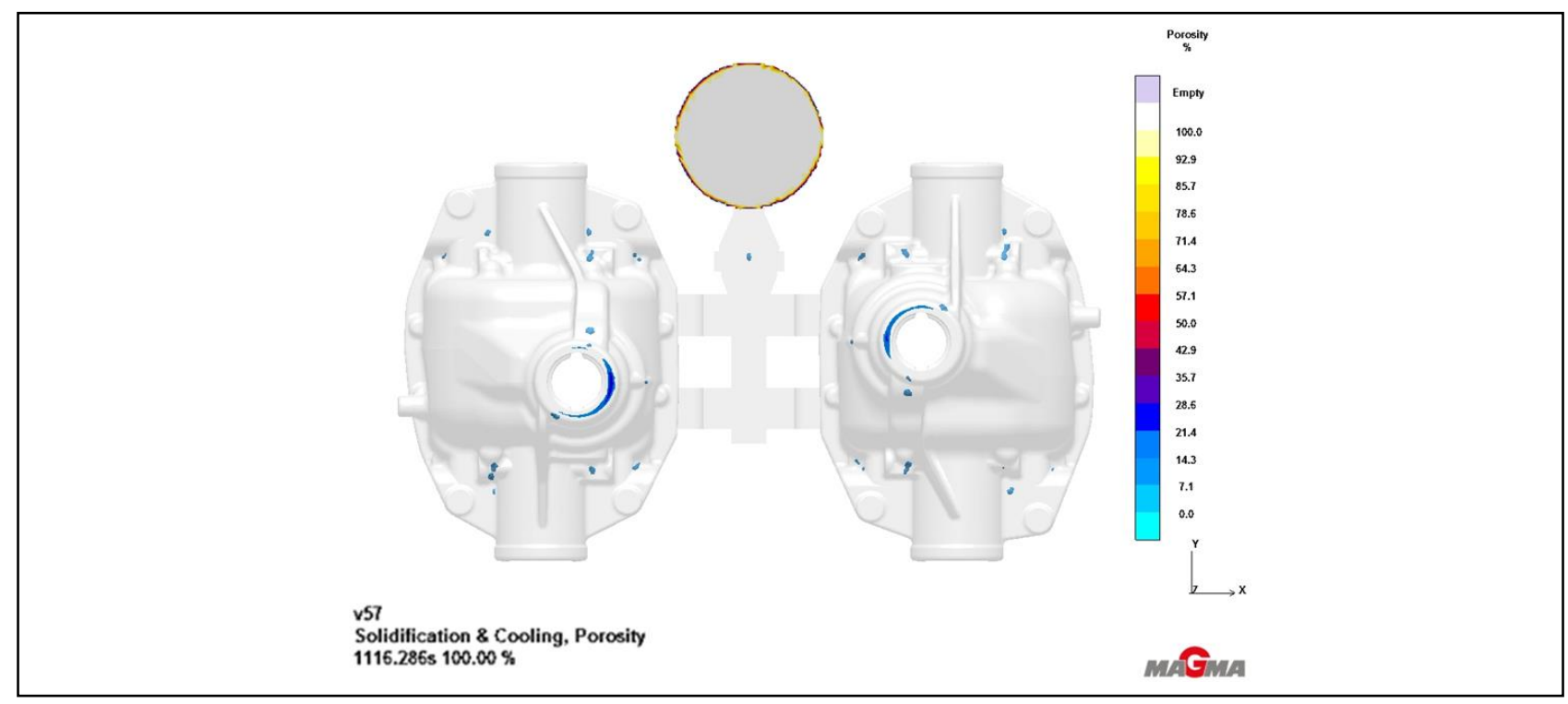

Fig. 19. Solidification. 
Erbul, A.; Vanli, A. S.; Akdogan, A. \& Durakbasa, N.: Gating System Design and ...

\section{Production and Scrap Analysis}

Production is realized for 5 boxes / 10 parts according to conditions which are determined before (Fig. 20, 21). The cold shut defect is detected during the scrap analysis (Fig. 22). After the production of 10 pieces, whole parts are investigated with $\mathrm{X}$-ray inspection (Fig. 22) and one of them is sectioned (Fig. 23). Investigations show that the simulation overlaps with the results of production. Cold shut defects are detected on the area which is predicted by simulation. In addition, the CC3-4 level (ASTM E446-15, 2015) shrinkage porosities are observed with X-ray and after sectioning. The locations of the porosities are estimated by simulation, precisely.
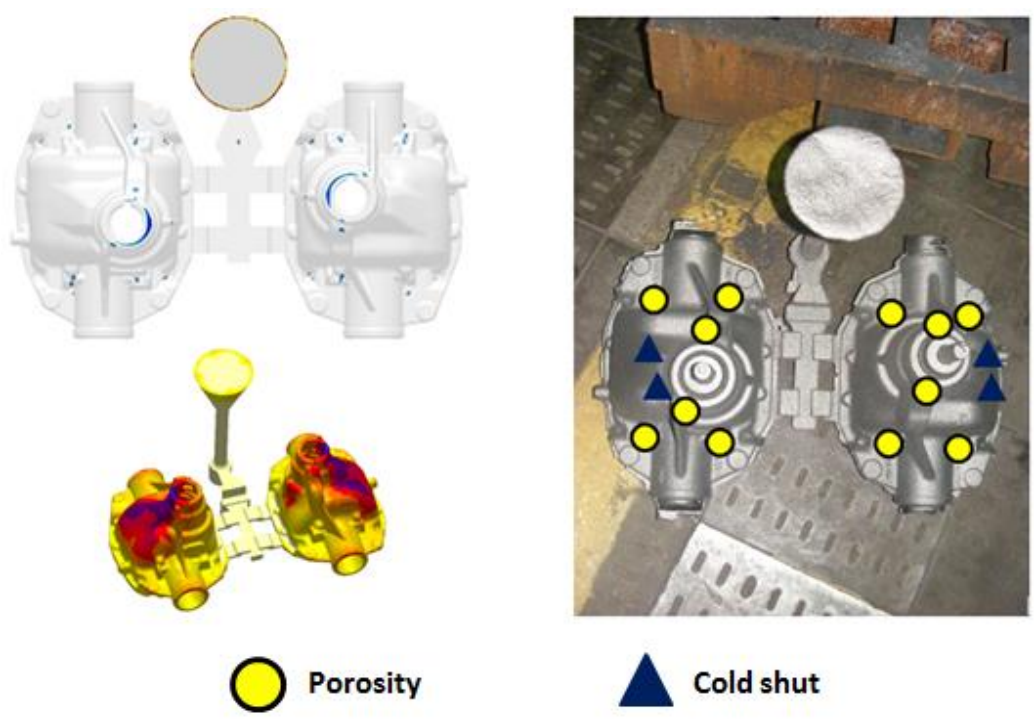

Cold shut

Fig. 20. Comparison of the simulation and production results.

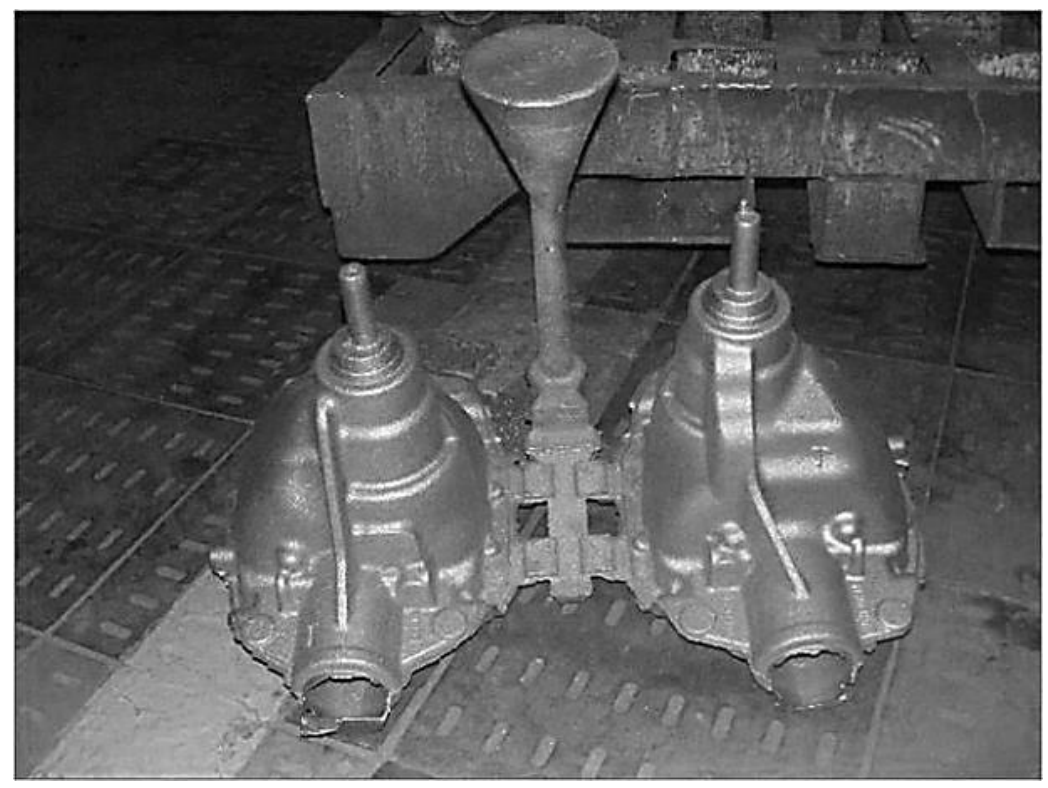

Fig. 21. The parts with gating system after production. 


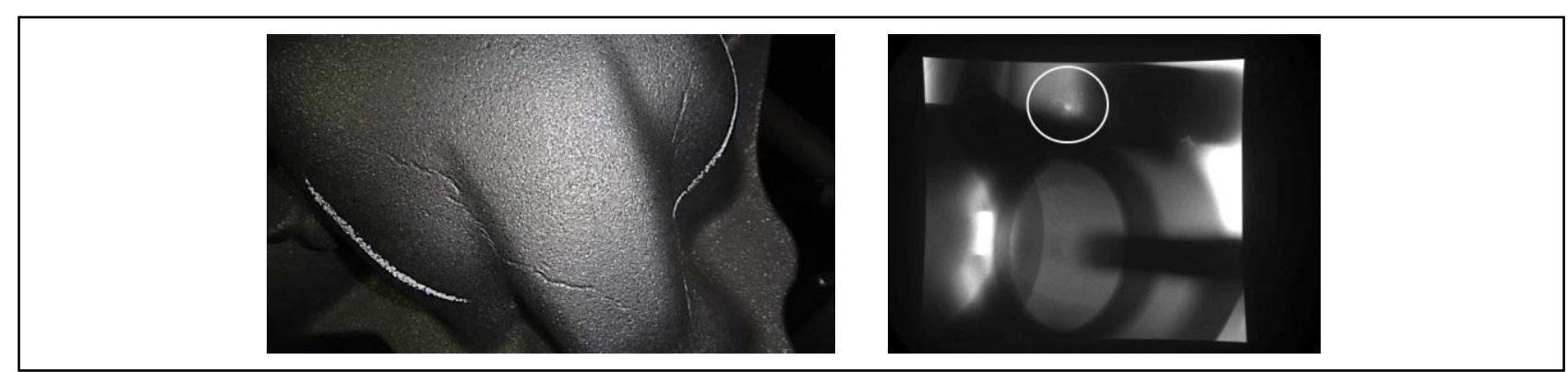

Fig. 22. Cold shut defect and X-ray inspection.

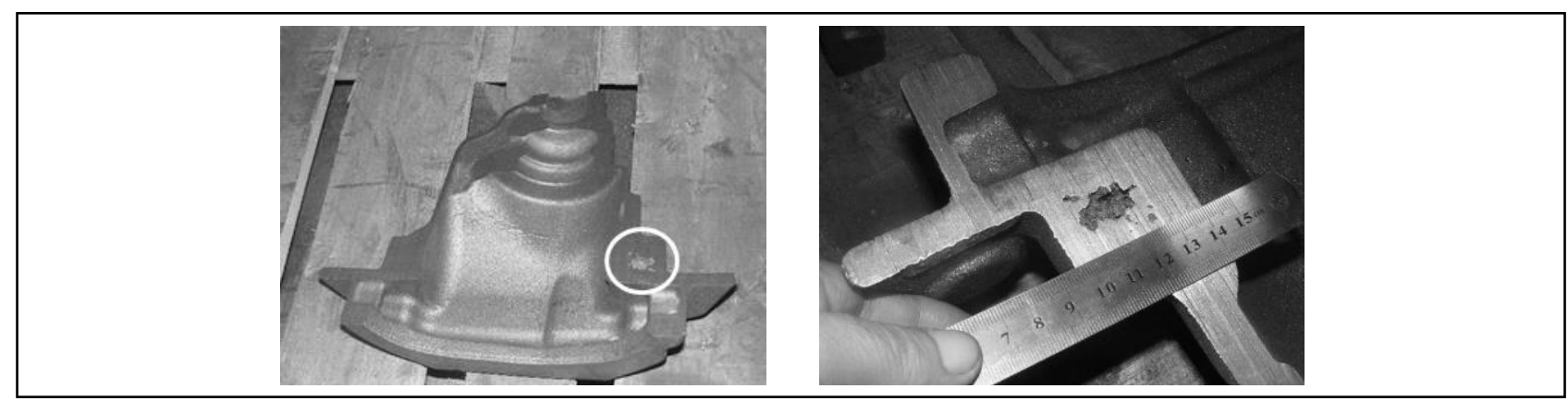

Fig. 23. The part sections.

\section{Redesign of the Gating System}

After scrap analysis, the simulation outputs are verified. Gating system is recalculated according to same approach and redesigned. Pouring temperature is increased to solve cold shut problem. Besides that, the part is surrounded by three gates to improve temperature distribution. At the same time, feeders are added in the system for the solution of shrinkage porosity issue. The new simulations are run and outputs are evaluated.

As shown in Fig. 24, molten metal velocity values at gates are changes between approximately $0,55 \mathrm{~m} / \mathrm{s}-0,85 \mathrm{~m} / \mathrm{s}$. There is no mold erosion risk detected after filter according to simulation output. If the new design and older one are compared with each other for cold shut risk, improvement can be seen, easily in Fig. 25. Since the first locations of the hotspots were on machining surfaces, it was needed to be solved or removed. As shown in (Fig. 26.), hotspots are approached to the feeders.

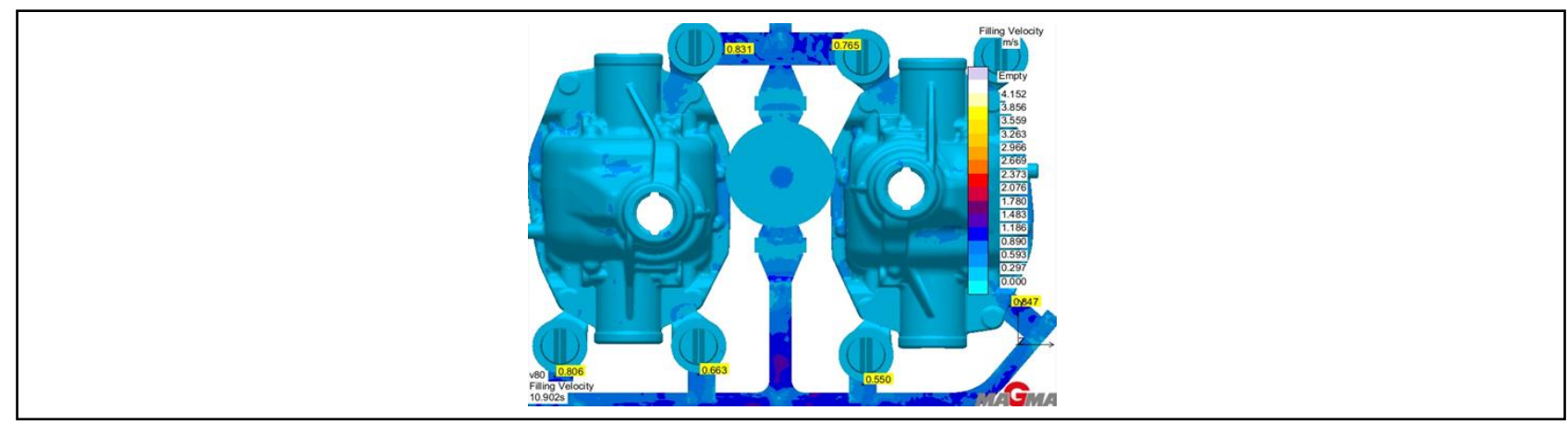

Fig. 24. Molten metal velocity at the gates of the new design. 
Erbul, A.; Vanli, A. S.; Akdogan, A. \& Durakbasa, N.: Gating System Design and ...

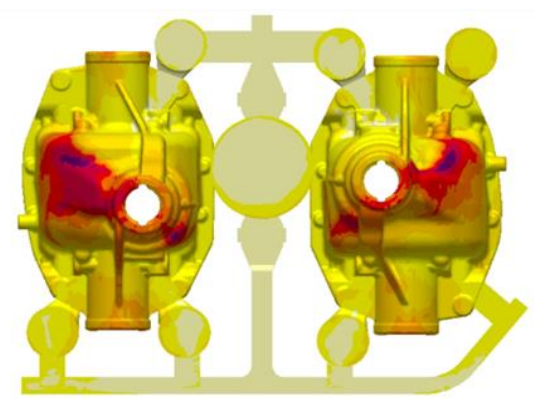

Fig. 25. Temperature distribution with the new design

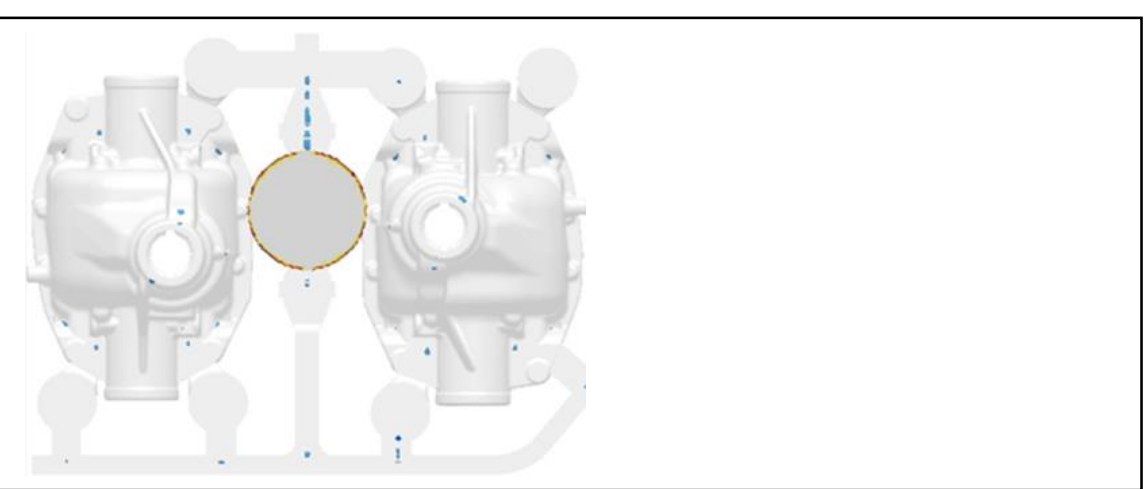

Fig. 26. Solidification of the new design.

\section{Production and Scrap Analysis of New Design}

New production was realized for 5 boxes / 10 again (Fig. 27). As shown in Fig. 28 , cold shut was not detected on both sides of the parts during visual inspections. Whole parts were checked by X-ray and one part was sectioned (Fig. 29) anew.

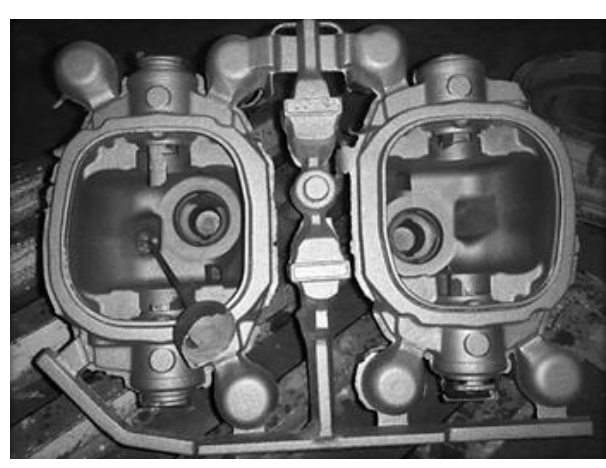

Fig. 27. The second production with new design.
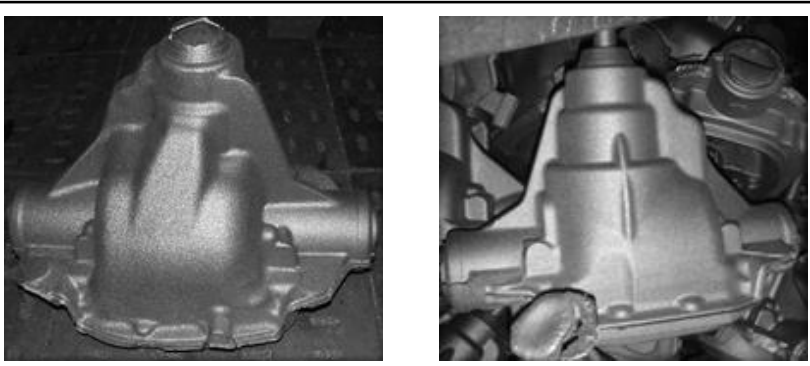

Fig. 28. Visual inspection of the part which was produced with new design. 


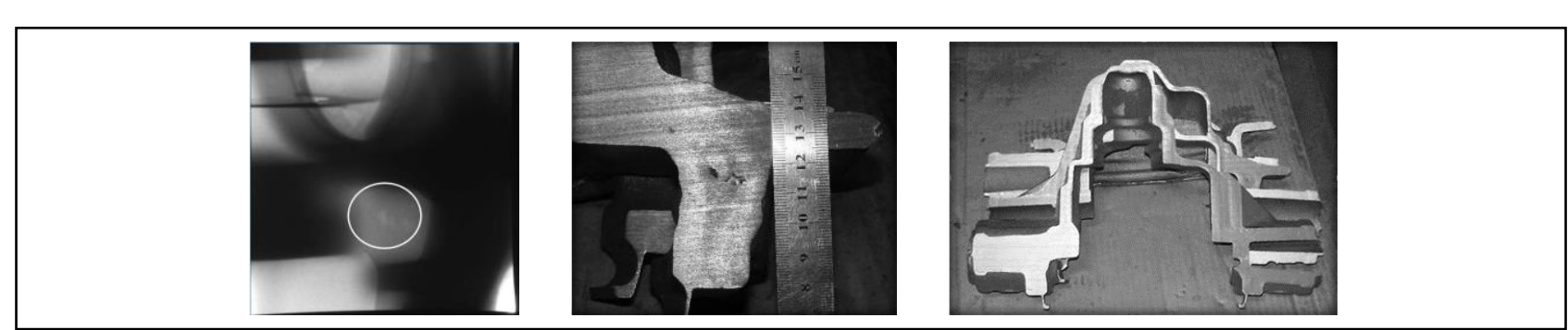

Fig. 29. X-ray inspection and section of the redesigned part.

\section{Conclusions}

There are many effective factors on product quality and mechanical properties in sand mold casting process. These factors consist of gating system design and various process parameters. Wrong selection of the process parameters for the casting operation can cause defective and low mechanical property products even they have perfect gating system designs. Therefore, the process should be thought as a whole and the process parameters should be kept in the optimal limits. Although, if the molten metal velocity parameter is convenient to casting, other problems can be occurred according to the gating system design. Therefore, all risk possibilities must be considered during the design stage of the gating system with the selection of the process parameters.

The comparison of the findings of the productions and the simulation outputs shows that the virtual results overlap with real. The simulations which were run with older design detected the cold shut risk and location of the shrinkage porosity. To solve the problems, the gating system was redesigned. Gates were placed around the part to keep warmer the parts and filling temperature was increased. When the parts which were produced with new design were checked, cold shut was not detected on any side of the parts. Besides that, shrinkage porosities were removed from the machining surfaces by feeders. And its level was reduced from CC3-4 to CC2-3. This level of shrinkage porosity is acceptable according to customer's related specification. But in the future, for improvement about shrinkage porosity problem, modification will be needed in this case. Material filling to place a riser can be implemented to reduce the shrinkage which is located at top neck of the part. To provide more effective work conditions for the side feeders which are already in the system, material filling can be implemented also on the parts which are between side feeders and problematic areas of the product. Even if the cold shut problem is solved, the wall thickness of the problematic area should be increased slightly to provide better flow for metal streams to be fused more easily.

Casting process parameters should be adjusted as optimum to meet customer requirements. Computer aided simulation is a unique way to determine optimum process parameters and to predict possible risks and casting defects. Since there are several defect types, estimation of process risks and taking precautions quickly and precisely before the production with the help of computer simulation is a must for casting processes. All findings shows that, the gating system design approach and well calibrated simulation software combination can avoid casting defects before the casting process. It creates opportunities to prevent wasting of material, energy, time etc. Besides that, it enables to find solutions quickly for improving the current processes. 
Erbul, A.; Vanli, A. S.; Akdogan, A. \& Durakbasa, N.: Gating System Design and ...

\section{References}

AFS (1947). Analysis of Casting Defects, Chicago, USA

ASM International (1998). ASM Handbook Volume 15 Casting, Ohio, USA

ASTM E446-15 (2015). Reference Radiographs for E446 Steel Castings Up to 2 in. $(51 \mathrm{~mm})$ in Thickness - Vol II + Active Standard, ASTM International, West Conshohocken

Bodsworth, C. (2001). British Iron and Steel AD1800-2000 and Beyond, IOM Communications, London, England

Brown, J.R. (2000). Foseco Foundrymen's Handbook, Butterworth, London, England Cavusoglu, E.N. (1981). Dokum Teknolojisi 1, Istanbul, Turkey: ITÜ Gumussuyu Matbaasi

Davis, J.R. (1996). ASM Speciality Handbook Cast Irons, Materials Park, Ohio, USA Demircioglu, N.S. (2013). Dokumculuk ve Modelcilik Teknolojisi 1, Pozitif Matbaacilik, Ankara, Turkey

EN 1563:2011 (2011), Founding - Spheroidal graphite cast irons, European Standard Erbul, A. (2017). Gating System Design in Sand Casting of Cast Irons and Investigating the Simulation Results, MSc. Thesis, Yildiz Technical University, Graduate School of Natural and Applied Sciences, Istanbul, Turkey

Erbul, A. \& Vanli, A.S. (2017). Unpressurized Gating System Design and Simulation in Sand Casting of Ductile Iron, Proceedings of 3rd International Iron\&Steel Conference, Yasar, M. (Ed.), pp. 601-608, ISBN 978-605-9554-0-60, Karabuk University, April 2017, Karabuk

Odabasi, A. (2004) Kokil ve Kum Kaliba Dokum Yontemleriyle Uretilen Yuksek Kromlu Beyaz Dokme Demirlerin X-isinlari ve Taramali Elektron Mikroskobu Calismalariyla Karakterize Edilmesi, MSc. Thesis, Istanbul Technical University, Graduate School of Natural and Applied Sciences, Istanbul, Turkey

Raz, K, Zahalka, M \& Polak. R (2016). Injection Molding Simulations of Hardly Producible Parts from PBT, Proceedings of the 27th DAAAM International Symposium, pp.0501-0505, B. Katalinic (Ed.), Published by DAAAM International, ISBN 978-3-902734-08-2, ISSN 1726-9679, Vienna, Austria

Rio-Tinto Iron and Titanium Inc. (2000), Ductile Iron: The Essentials of Gating and Risering System Design, Montreal, Canada

TUDOKSAD-Turkish Casting Industry Associations (1999), Dokum Hatalari Atlasi, Istanbul, Turkey 